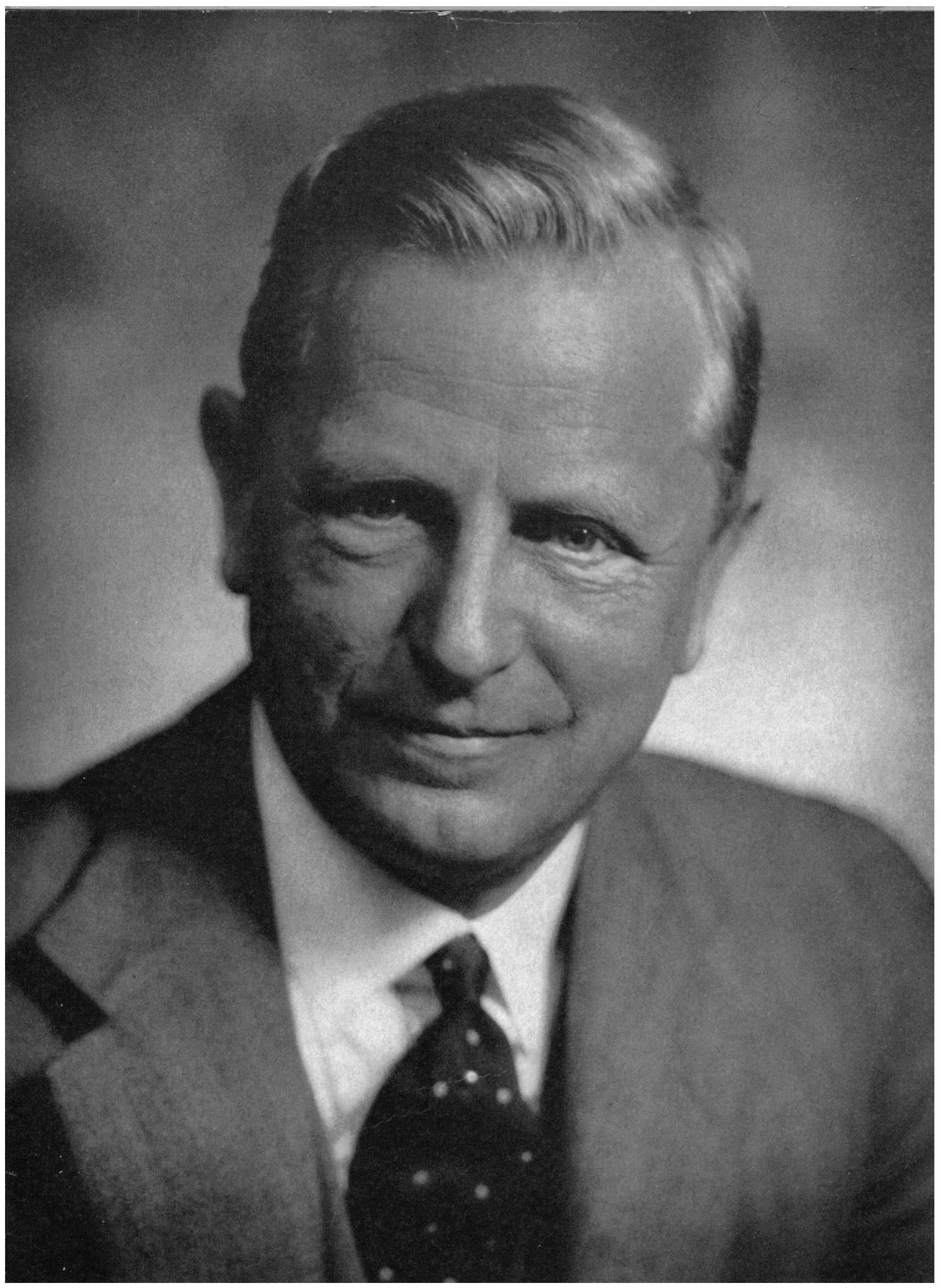

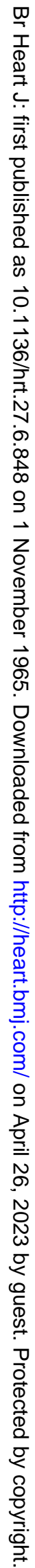




\title{
JOHN HAY AND THE FOUNDERS OF THE CARDIAC CLUB*
}

\author{
BY \\ CRIGHTON BRAMWELL
}

In the first place let me say how greatly I appreciate the honour of being invited to deliver this lecture, and what a pleasure it is to have the opportunity of paying tribute to one whose friendship I had the good fortune to enjoy for very many years.

John Hay was one of the most distinguished and most respected physicians of his day; moreover he had a real genius for friendship. One simply couldn't help liking him, he was so straight, so modest, and so full of fun. He was a man of high ideals, a lifelong teetotaller, but always tolerant of those whose views might differ from his own. In his prime, he was a remarkably young-looking man for his age, and even in later life he still enjoyed the vigour and enthusiasm of youth. Towards the end, when his sight began to fail, he tolerated this affliction with wonderful equanimity, and to him, a talented artist, an ex-president of the Liver Sketching Club, and a keen and knowledgeable gardener, it must have been a terrible disability. On one of the last occasions that I saw him, he took me and my wife into his charming little garden in Bowness and, though he could no longer see the flowers himself, he still got enjoyment from them. Doubtless they brought back many happy memories.

Maurice Campbell and Wyn Jones have truly said that Hay was skilled in the science of medicine and a supreme master of the art. On the various occasions when I met him in consultation, I was always impressed by his ability to inspire his patient with confidence and courage. He was a fine example of what Rae Gilchrist has so aptly called "The Compleat Physician".

In his early days, he was closely associated with Sherrington and James Mackenzie. Probably it was these two brilliant men who aroused his interest in research and led him to investigate cardiac function by graphic methods. Hay founded the first cardiac clinic in the north of England, at the Liverpool Royal Infirmary, but his interests extended far beyond cardiology, and on one occasion 'when asked in what he specialized, he said "Human Beings". As a teacher of outstanding merit, he served his school well, and in recognition of his services to the community he was made a DeputyLieutenant of the County Palatine of Lancaster.

One of the many things that must have contributed to John Hay's enjoyment of life-and he did enjoy it-was his sense of humour. He could see the amusing side of even the most trivial incident. I remember a tale he told me about examining in Manchester. Their candidate was what, in Lancashire, we would call a "gormless" creature-a dull dog. They were discussing the treatment of fever, and Hay asked him "What else would you do for your patient?" .. . "I'd give 'im cauld drinks." .. . "Yes, very good, would you give him cold water, or cold tea, or cold beer or what?" ... "I see nowt wrong wi' cauld beer."

In the quest for a suitable topic for this lecture, it struck me that it might be appropriate to speak of some of John Hay's friends and contemporaries-the founders of the Cardiac Club: for the British Cardiac Society is the child of the Cardiac Club - a lusty child, a credit to its parent-and to the younger members of the Society some of those to whom I shall refer must be only names.

* The first John Hay Memorial Lecture, delivered at the University of Liverpool during the meeting of the British Cardiac Society on April 8, 1965. 
There were fifteen original members of the Club, and it may surprise you when I say that only two of these were cardiologists-Tom Cotton and John Parkinson. Thomas Lewis was really a physiologist, or, as he called it, a clinical scientist. All the other twelve were general physicians. That they were pretty good physicians is suggested by the fact that six of the twelve were, or became, Professors of Medicine in their respective schools-Cowan in Glasgow, Emanuel in Birmingham, Griffith in Leeds, Hay in Liverpool, Hume in Durham, and Ritchie in Edinburgh. In addition MacIlwaine was Professor of Pharmacology and Therapeutics in Belfast, and Wilkinson held the corresponding chair in Birmingham.

That cardiology was the chief interest of so many able physicians is no doubt due to the fact that great advances were being made in that field at that time, advances largely inspired by the genius of one man-James Mackenzie. It was, in fact, Mackenzie who originally suggested the formation of such a Club. As Cowan expressed it, "The Cardiac Club was conceived in Burnley before the first world war"; but it was not born till 1922, when, following the meeting of the Association of Physicians in Oxford, Cowan and Hume called together a group of men especially interested in heart disease. Most of these men had been associated with Mackenzie before the war and, as consultants to the Army and the Ministry of Pensions, they did valuable work. They brought cardiology up to date.

In 1914, the conception of heart trouble in the fighting services was, to say the least of it, primitive. Diagnosis was based on auscultation and had not advanced since the days of Laennec. If you heard a murmur the man had "VDH" (valvular disease of the heart), if you didn't it was "DAH" (disorderly action of the heart). This made cardiology delightfully simple, for VDH was organic, but DAH was functional. So, if a man had VDH, he had to be discharged, but if it was only DAH, he could be cured and returned to duty.

The conception of VDH was perhaps not quite so fantastic as might appear at first sight, for we were dealing with young men and, in them, the only common types of heart disease are rheumatic and congenital, both of which generally manifest themselves by murmurs. Ischæmic heart disease and hypertension are rare in this age-group.

Where the diagnosis did come to grief was the failure to realize that a murmur might be due to causes other than heart disease. This had been pointed out by George Balfour of Edinburgh in 1882. He coined the term "curable mitral incompetence" for the systolic murmur heard in patients suffering from chlorosis, a murmur that disappeared when the anæmia was successfully treated. This had been emphasized by Balfour's pupil and house physician-Graham Steell—and by Steell's great friend and contemporary James Mackenzie, both of whom had taught that the heart muscle was more important than the heart valves. But in 1914 this lesson had not been driven home, and many doctors still believed that a murmur was synonymous with heart disease.

In speaking of individual members of the Club, I need not refer to Tom Cotton* or John Parkinson, for they happily are still with us. The others I have arranged in the order of their date of birth.

Born in 1861, more than a hundred years ago, Wardrop Griffith was the doyen of the Club. He was the son, and what is more he was the eighth son, of Charles Fox Griffith, an Aberdonian and a Justice of the Peace. If the other seven had the physique of Wardrop, they would have made a grand crew at Henley! Whether Wardrop had any younger brothers I do not know.

Aberdeen has produced many distinguished men, whole families of them like the Andersons and the Geddeses. Personally I have a very soft spot for Aberdeen, for it was there that I caught my first two salmon, when examining in medicine with that great sportsman-Stanley Davidson. Examining north of the Tweed is far more fun than in England. At St. Andrews, for example, Ian Hill has decreed that, at the June examination, all the examiners in medicine shall devote one whole day to research on the visual acuity of Salmo Fario (the common trout).

Griffith was a very striking figure, especially in uniform - tall, handsome, straight as a ramrodhe had the carriage of a guardsman. He was said to be a strict disciplinarian; but, from personal knowledge, I can vouch for his being a very kindly man. In 1920 I went to Leeds to see him and

\footnotetext{
* Thomas Forrest Cotton died on July 25, 1965, aged 80.
} 
he gave up a whole day to initiating me into the mysteries of the polygraph. He was a lifelong friend of James Mackenzie who was only eight years his senior. Educated at Aberdeen grammar school and Aberdeen University, he went to Leeds where he was RMO at the Royal Infirmary for four years and then was appointed Professor of Anatomy, at the early age of 26. He was a dramatic lecturer and used to jump onto the table to illustrate the action of muscles and joints. As anatomy was a part-time chair, he also engaged in private practice and, in due course, was appointed to the staff of the Royal Infirmary. He held the chair of anatomy for 23 years and then transferred to the chair of medicine-a truly remarkable achievement. At the Leeds meeting of the Club in 1934, we were all greatly impressed by his skill as an artist on the blackboard and by his lucid description of many types of congenital heart disease. Griffith had a remarkable memory and would recite verbatim long passages from Thackeray, Scott, and Gilbert and Sullivan. For his services in the first world war he was created C.M.G.

John Marshall Cowan was one of the aristocrats of medicine. His father was Professor of Materia Medica and his grandfather Professor of Medical Jurisprudence in the University of Glasgow. His great grandfather, a surgeon, was part-time Professor of Botany at the Anderson College of Medicine in Glasgow where, three generations later, John Cowan himself became Professor of Medicine. In those days botany was one of the most important subjects in the medical curriculum. He was naturally very proud of his medical ancestry which extended back eight generations to Patrick Marshall, a surgeon of Kilsyth who was born in the year 1631, and so was a contemporary of the greatest cardiologist of all time-William Harvey. He wrote a charming little book entitled "Some Yesterdays" about medical education in the time of his forebears.

Cowan was a very cultured man of great personal charm. Had he been a diplomat instead of a doctor, he would have made a fine ambassador. He was physician in Scotland to George V, Edward VIII, and George VI, and, what especially pleased him, a member of the King's bodyguard for Scotland-the Royal Archers. In the Boer War, he served with the Scottish National Red Cross Hospital, and in the first world war he was consulting physician to the Egyptian Expeditionary Force. He was educated at Fettes, King's College Cambridge, and Glasgow University. Being a Cambridge graduate in medicine, he may have learnt from that great scholar-Clifford Allbuttthe importance of clarity of expression, which characterized all his writings. His book on heart disease, in the later editions of which he had the co-operation of William Ritchie, was for many years the textbook of its day. Like Allbutt, Cowan always spoke of āngina, not ăngina. How much more euphonic, and more correct, so my classical friends tell me. Another expression of Cowan's which always intrigued me was "outwith"-evidence of his Scottish nationality.

Hume and Cowan were chiefly instrumental in founding the Cardiac Club, and Cowan was its first secretary.

I have said that most of the original members of the Club were general physicians whose chief interest was cardiology. That was not true of Thomas Horder (later Lord Horder of Ashford). He had so many interests and might well have claimed to be a specialist in half-a-dozen branches of medicine. He was one of the last of the great general physicians. It is not surprising that he had a large consulting practice and numbered among his patients two monarchs and three prime ministers. In his early days he was keenly interested in clinical pathology, and it was his brilliant work on the bacteriology of infective endocarditis that led to his being invited to join the Club.

Horder was a great committee man, and had a finger in every pie: he founded the Fellowship for Freedom in Medicine; he was chairman of the Empire Rheumatism Council and of the British Empire Cancer Campaign; and he championed the cause of smoke abatement and of noise abatement. I will not weary you with a list of his many hobby-horses, but will merely say that his innumerable activities embraced the whole span of human life from birth control to cremation!

Joseph Emanuel was one of the kindest and most humble men I ever met. He was Professor of Medicine in Birmingham. A great teacher who, by his example, taught his students what they could never learn from any textbook-courtesy, sympathy, and understanding. He kept abreast of the most recent advances in medicine, but did not hesitate to criticize innovations that he considered 
were not advances. I am sure he would have endorsed the sentiments of that great physicianRobert Hutchinson-who said, "From too much zeal for what is new and contempt for what is old, from putting knowledge before wisdom, science before art and cleverness before commonsense, and from treating patients as cases, Good Lord deliver us!"

The sweetness and goodness of his character endeared him to his colleagues and, when in 1939 the Association of Physicians met in Birmingham, it was Emanuel they chose as their President. He was a pioneer in investigating the cardiac arrhythmias with the polygraph, and introduced the electrocardiograph to the Midlands. Both he and his wife were enthusiastic mountaineers and used to climb in North Wales, the Alps, and the Pyrennees.

Emanuel was unique amongst members of the Club in that in 1897 he went on a voyage to Australia as medical officer in a sailing ship-an experience unusual even in those days. Brenner has told us how he gained a reputation on that voyage, not for treating a sailor seriously injured in a storm, when he himself was almost prostrate with sea-sickness, but for the anxious care with which he looked after the ship's cook to whom he had inadvertently given an overdose of calomel!

William Ritchie was treasurer of the Club for the first ten years of its existence, after which the office was merged with that of secretary. He was a shy man, but being a contemporary and close friend of my elder brother, I got to know him well and had a high regard for him. He was President of the Royal College of Physicians of Edinburgh and Professor of Medicine in Edinburgh University, where he was greatly respected for his single-minded devotion to his hospital and university work.

Ritchie was one of Mackenzie's first disciples, but it was George Gibson of Edinburgh who was responsible for arousing his interest in cardiology. He was clinical tutor to Gibson for four years. His classical monograph on auricular flutter, which he recognized while studying heart-block with the polygraph, was published in 1914. The following year he went to Gallipoli as medical officer to the $1 / 3$ Scottish Horse and was later in charge of the medical division of a general hospital in Egypt.

Ritchie had a curious little mannerism. He used to say "Eugh" at the end of every sentence, and one day when teaching the normal heart sounds to a class of beginners, he asked "Now can you hear that 'lub; dup'? Eugh." "I can hear the lub, dup, Sir, but I can't hear the Eugh." It was Alexander Gibson, not Ritchie, who discovered the third heart sound!

Hubert Starling, like his elder brother Ernest-the distinguished physiologist-was a Guy's man. He was a civil surgeon in the Boer War and then settled in general practice in Norwich. In 1914, to his great disappointment, he was rejected for the Army on medical grounds, but later obtained a commission and, on Mackenzie's recommendation, went to work at Colchester with Lewis who was investigating the problem of the so-called "soldier's heart". After the war, he became a consultant and was appointed to the staff of the Norfolk and Norwich Hospital.

Starling and Hay were the musical members of the Club. Hay played the violin and viola and was a regular patron of the Royal Liverpool Philharmonic Society. Starling was an accomplished organist and a prominent member of musical circles in Norwich. In his younger days, he had a good singing voice and, in later life, a cheery booming laugh.

John MacIlwaine was a very popular Queensman and an Irish Rugby international. His father was one of the pioneers of the Belfast shipbuilding industry, and he himself originally intended to be an engineer. He took a B.Sc. degree in naval architecture at Glasgow University, but then switched over to medicine. In his final year he volunteered for service in the Boer War, and went out as a dresser in the Irish Hospital to the South African Field Force. His engineering background may have accounted for his fascination with the electrocardiograph, and in due course he was appointed physician in charge of the Cardiographic Department of the Royal Victoria Hospital in Belfast. Later he became Professor of Materia Medica and Therapeutics and was President of the Ulster Medical Society. Unfortunately he went blind, through detachment of the retina, and died at the age of 56.

Alexander Gibson was a shy, retiring, and very charming man. In 1925 he succeeded Cowan as Secretary to the Club. Educated at University College Aberystwyth (where incidentally he read 
agriculture), Christ Church, and St. Thomas's, he settled in Oxford, where he was closely associated with Osler. He was secretary to the editors of the Quarterly Journal of Medicine for thirty years, and latterly was an editor as well. Gibson was both physician and pathologist to the Radcliffe Infirmary. In 1907 he published his paper on the third heart sound, which he was the first to describe and with which his name will always be associated. He was a good teacher, and evidently believed in early rising, for, during the summer term, he held his first class of the day at 7 a.m.!

It would be hard to improve upon Lord Dawson's description of Carey Coombs: "A man who both in body and mind was fashioned on broad lines-his outlook large and generous." His book on rheumatic heart disease, published in 1924, is a classic and gives an admirably clear and authoritative account of knowledge of the subject at that time.

He was director of the Cardiac Research Centre of the University of Bristol and Physician to the Children's Hospital as well as the Bristol General Hospital. Realizing the importance of education for children who had to spend many months in hospital, and later would be dependent on their brains for earning their living, he developed the idea of school-hospitals for his young cardiac patients, so that treatment and education might proceed hand in hand. Coombs' contributions to cardiology were not confined to rheumatic heart disease, his Lumleian lecture was devoted to cardiovascular syphilis, and he did valuable work on endocarditis lenta - that tragic disease so prevalent amongst pensioners from the first world war.

William Hume was a Northumbrian. His father was an honorary surgeon to the Royal Victoria Infirmary at Newcastle, where he himself was appointed assistant physician at the early age of 28 , and full physician six months later. To this institution he was intensely devoted, and wrote a short history of the Infirmary in 1951, when it celebrated its bicentenary. The following year he was knighted.

He was educated at Repton, Pembroke, and the London Hospital, where he clerked for Bertram Dawson (later Lord Dawson of Penn) and became his life-long friend.

In consultation, Hume always treated both patient and doctor as sane, intelligent people who expected to know the truth. In the first world war, he was consulting physician to the First Army in France and in recognition of his services was created C.M.G. It was a good war for Hume, for in France he met his future wife, the charming daughter of a distinguished officer in the French army who had been military attaché in Madrid. Although cardiology was his chief interest, he made valuable contributions to many other fields of medicine including war nephritis, spirochætal jaundice, and encephalitis lethargica.

Hume and Hay had much in common. Hume did for Newcastle what Hay had done for Liverpool. He introduced the electrocardiograph to the north-east, and, when the time came for him to retire from the Chair of Medicine and the Royal Victoria, he joined the staff of the Newcastle General Hospital and was largely instrumental in founding the Regional Cardiovascular Department there.

Hume's activities were not limited to the north, for his ability was widely recognized. He became censor and senior censor of the College of Physicians and, in 1943, was appointed Harveian Orator. As a censor he was a formidable but kindly examiner, emphatically clinical in his outlook, with no use for the candidate who knew all the biochemical tests but did not know how to elicit the knee-jerk.

In his tastes, he was essentially a countryman, and spent many happy hours salmon fishing on the Tweed. Unfortunately, in his later years, his activities were increasingly limited by severe arthritis, but to the very end he retained his interest in medicine and in men. Like Hay, Hume had a keen sense of humour. He sent me a Christmas card depicting three very bedraggled and scruffy-looking musicians playing "Christians Awake". Above was a peppery old colonel, in his pyjamas, hurling a boot at them from his bedroom window. The caption read "Look out Bill, the Christians 'ave awoke!"

Thomas (later Sir Thomas) Lewis decided to become a doctor before he reached his teens, for both family doctors were conjurers. He was, in some ways, the very antithesis of John Hay-a difficult 
man to get to know, very reserved, with a somewhat gruff manner, due I think to shyness. Unlike Hay and Mackenzie who were skilled in both the science and the art of medicine, Lewis had little aptitude for the art. He was a physiologist rather than a physician, and it was only because he felt doubtful whether he could earn his living in medical research that he engaged in practice. This was obviously not his line and he gave it up in 1916, when he was appointed physician to the Medical Research Committee (as the Medical Research Council was then called) and no longer needed two strings to his bow. Two years later he was elected a Fellow of the Royal Society. Lewis was a superb craftsman and showed that the critical standards of science could be applied at the bedside to the study of disease in man.

Time will permit me only to mention his researches on auricular fibrillation, on pain, and on the vascular reactions of the skin, and his many books, of which probably the most outstanding was "The Mechanism and Graphic Registration of the Heart Beat", published when he was only 30 years of age. In 1909, with the help of James Mackenzie, he founded the journal Heart which he edited himself. Later he enlarged the scope of the journal, changed the title to Clinical Science, and handed it over to the Medical Research Society which he had founded. His hobby was bird photography.

Kenneth Wilkinson was a character and very good company. When I stayed in his house, or he in mine, we never got to bed before midnight. A brilliant raconteur, with a fund of amusing stories which he told in various dialects, he could easily have made his living as a comedian on the music hall stage.

He was a member of the British Pædiatric Association as well as of the Cardiac Club, a general physician, and Professor of Pharmacology and Therapeutics. As a pædiatric cardiologist, his chief interests were naturally rheumatic heart disease and diphtheritic myocarditis. In those days, congenital heart disease was still the province of the anatomist and, apart from Wardrop Griffith's communication at Leeds in 1934, I cannot recall more than casual reference to the subject at any meeting of the Club and, of course, Griffith was an anatomist. With his friend Whitmore Peck, Wilkinson wrote an excellent life of William Withering and, when the British Cardiac Society met in Birmingham in 1939, we dined under Withering's portrait, in the beautiful mansion which had been his house.

Wilkinson's hobbies were as varied as his clinical interests: he was a good golfer, a good bridge player, a yachtsman, a philatelist, and a bee-keeper. John Hay and Kenneth Wilkinson were the great photographers of the Club. At our meetings, Wilkinson was always hung about with cameras, exposure meters, and what not, like a christmas tree. He had no great sartorial ambitions and sometimes looked as if he had gone to bed in his trousers. No meeting of the Club would have been complete without Wilkinson. We all loved him.

The only honorary member of the Club was James Mackenzie, and it was fitting that this was so, for no British cardiologist, in his day or since, has been in the same class. John Cowan, a fellow Scot, described him as-" A tall burly man with all the directness of the North. He seemed at first sight rather dictatorial and overbearing, but his transparent goodwill, his unselfishness, and his humility soon made manifest that it was only his intolerance of sham and his search for truth. He took a kindly interest in all his neighbours, especially the younger members of the profession, and he was always receptive of opinions based upon material which was outwith his own opportunity."

As a student in Edinburgh, he won no special distinction. His great work was done during the 28 years he was in general practice in Burnley. There, with the help of a local watchmaker, he produced his clinical polygraph which, by co-ordinating the venous with the arterial pulse, enabled him to distinguish between the dangerous and the harmless types of cardiac irregularity. From his obstetric practice in Burnley, he learned the hazards of child-birth in women with heart disease. But, most important of all, the careful records of his patients revealed the significance of symptoms. This enabled him to establish a rational prognosis for heart disease and to overthrow the dictatorship of the stethoscope which had dominated cardiology for nearly a hundred years.

Later, in London and St. Andrews, he imparted to others the fruits of his wisdom in teaching, 
practice, and the direction of research. One cannot but marvel at such achievements. The hours for research were literally snatched from the rush of general practice. But, in a man of Mackenzie's temperament, the urge to contribute to knowledge and to the welfare of his fellow men is overwhelming and, no matter how extensive his other commitments might be, that urge prevails. Abraham Flexner, the greatest of all champions of the full-time principle in medicine, once said: "Really determined and fertile minds will continue to produce on part-time or on almost no time at all."

On May 28, 1925 the Cardiac Club recorded the following minute-

"The Cardiac Club laments the death on January 26th 1925 of its Honorary member, Sir James Mackenzie. By the power of his genius and the wealth of his achievements he exercised a vast influence upon the branch of medicine with which his name is indissolubly associated, and his preeminence, transcending the limitations of race and clime, was universally acknowledged. So long as the science of medicine endures, so long will the name of Sir James Mackenzie be honoured.

This tribute is rendered to the memory of him, whom all members of the Cardiac Club revered as their master; and the Club respectfully offers its sincere sympathy to Lady Mackenzie and Miss Mackenzie in the great loss which they have sustained."

I fear I have given a very inadequate account of the achievements of the Founders of the Club, but I have been concerned more with what they were than with what they did. They were pioneers, and those of us who later joined the Club were proud to be associated with them and to share their friendship. Friendship was the hallmark of the Cardiac Club.

On the other side of the Atlantic, they have a word, for which we have no equivalent over herea word they use to describe a man they admire from every point of view. When first I heard it, it struck me as a strange word to use in such a context; but, when I got to understand its meaning better, I realized how descriptive it was. In America they would say John Hay was a "lovely man". His life was a full and happy one. His name will long be remembered, and perpetuated by his two able sons. 